DOI: https://doi.org/10.31392/NZ-npu-144.2019.10

УДК $377(430)$

Дубина Л. О.

\title{
ОСОБЛИВОСТІ ФУНКЦІОНУВАННЯ ПРОФЕСІЙНОЇ СИСТЕМИ ОСВІТИ ФЕДЕРАТИВНОЇ РЕСПУБЛІКИ НІМЕЧЧИНИ
}

У статті подано характеристику особливостей функиіонування системи професійної освіти Федеративної Республіки Німеччини (ФРН). Дуальна система професійного навчання в ФРН - ие одна з характерних особливостей німецької системи професійної освіти, що відрізняє ї̈ від системи освіти іниих економічно розвинених країн. В результаті аналізу літератури виявлено адаптаційний потениіал системи професійної освіти ФРН для української системи професійної освіти. Схарактеризовано тендениії розвитку імодернізаиії німечької системи професійного навчання.

Ключові слова: професійна освіта, професійне навчання, виробниче навчання, дуальна система, учні.

Результативність сучасної професійної освіти у ФРН залишається на високому рівні попри наявні соціальне напруження і темпи розвитку економіки Євроспільноти. Система професійної освіти Федеративної Республіки Німеччини сьогодні забезпечує підготовку кваліфікованих кадрів не тільки для національних, але і європейських підприємств. У зв'язку з цим, вивчення досвіду розвитку системи професійної освіти Німеччини $€$ особливо актуальним для системи освіти України. Німецька система середньої професійної освіти тривалий час була зразком для інших країн. Система німецької середньої освіти формувалася впродовж століть.

Наразі в Україні реалізовано проект “Дуальна освіта в діалозі", профінансованого Міністерством закордонних справ ФРН [3]. 3 огляду на перспективи розвитку дуальних навчальних напрямів в Україні доцільно дослідити особливості функціонування професійної системи освіти ФРН.

Впровадження елементів дуальної системи підготовки кваліфікованих робітників в експериментальних освітніх закладах України висвітлило проблемні аспекти поширення елементів дуальної освіти [4].

І. Бойчевська досліджуючи дуальну освіту в Німеччині дійшла висновку, що така освіта $є$ надає їй найкращі можливості для отримання кваліфікації. Вона $є$ основним джерелом формування молодої генерації кваліфрікованих робітників і завдяки тісному зв'язку зі сферою праці забезпечує оптимальний старт трудового життя [1, с. 73].

Заслуговує на увагу позиція М. Міллєра (Miller M.), який зробив аналіз підходів до характеристики професій майбутнього. На його думку, той хто сьогодні обирає професію, повинен знати, що буде потрібно у майбутньому, в чому буде сутність економічних можливостей через 5 або 10 років [6, с. 56].

У зв'язку з цим для учнівської молоді при переході від школи у світ праці загострюється невпевненість у власному професійному майбутньому. 3'являється настирлива потреба у списках професій, які будуть потрібні на 
ринку праці 2020 і подальших років, а які ні. Зростає вагомість інфрормації про те, які професії будуть пріоритетними у зв'язку з їх модернізацією або/i їх ексклюзивністю; які професії, не зважаючи на всі структурні зміни, не підпадуть під безробіття; які профресії будуть виконувати прогресивні функції у зв'язку з швидкими якісними і кількісними змінами стандарту праці.

В умовах сучасного виробництва у Німеччині створюється новий тип робітника, основними особливостями якого $€$ широко профрільна професійна підготовка,високий рівень загальної культури і загальноосвітньої підготовки. Функції кваліфрікованого робітника обіймають: спостереження, програмування, управління. Це не вимагає фрізичних витрат, але натомість висуває нові вимоги до розвитку інтелектуальних, комунікативних здібностей, здатності до подальшої освіти і самоосвіти. Основна школа, крім обов'язкової загальної освіти забезпечує підготовку до навчання у професійних школах і подальшому вибору профресії. Реальна школа $€$ навчальним закладом посиленої професійної спрямованості і пропонує учням дві перспективи: 3 одного боку, вона готує їх до розв'язання практичних життєвих завдань з підвищеною предметною і соціальною відповідальністю, з іншого боку, учні можуть перейти до професійної або загальноосвітньої школи, наприклад, до старших класів гімназії.

По завершенню основної школи (9 клас) і реальної школи (10 клас) учні вступають до закладів професійної освіти і на 12 рік навчання завершують профресійну підготовку [6, с. 4].

Мета статті - схарактеризувати особливості фрункціонування системи професійної освіти Федеративної Республіки Німеччини.

Сучасний ринок праці висуває високі вимоги до кваліфрікації робітника. За даними німецьких кадрових агенцій, роботодавець при прийомі на роботу нових співробітників, перш за все, звертає увагу на наявність одного чи декількох дипломів про освіту і сертифікатів додаткової підготовки; досвід роботи; готовність до професійного зростання; ініціативність; відповідальність; мобільність; уміння планувати і прогнозувати; уміння конструктивно розв'язувати проблеми в колективі; здатність до раціональних, аргументованих, рефрлексивних рішень. Зазначимо, що більшість дослідників професійної освіти і роботодавці вважають безпосередній перенос у практику школи вищезазначених якостей робітника недоречним, бо мотивація учня відрізняється від мотивації дорослої людини, орієнтованої на кар'єрне і професійне зростання. Отже, школа повинна створювати простір і умови для формування цих якостей і окреслити реальні межі вікової компетенції школяра на різних етапах його навчання. Необхідність розвитку компетенцій вже в межах шкільної освіти обумовлено змінами в житті суспільства, особливо в сорері праці.

Середня професійна освіта в Німеччині - наступний щабель після неповної середньої школи. До системи середньої професійної освіти зараховують середні професійні освітні заклади, а також технікуми, у які на відміну від технікумів в Україні, не можна вступити після неповної середньої 
школи і навіть після гімназії. Для вступу в технікум необхідно вже мати середню професійну освіту.

До системи середньої професійної освіти у Німеччині зараховують:

- професійні школи (Berufsschulen) в межах дуальної системи;

- професійно-техінічні школи (Berufsfachschulen) і школи середнього медичного персоналу (Schulen fur Berufe im Gesundheitswesen);

- технічні школи (Fachoberschulen);

- профресійні училища (Berufsaufbauschulen);

- технікуми (Fachschulen) [2, с. 43-44].

В окремих землях Німеччини є і інші типи закладів середньої професійної освіти: коледжі, професійні, економічні гімназії і т. ін.

Середні професійні заклади Німеччини можуть бути державними, приватними або мати змішану правову форму власності. Так, наприклад, дуальна система навчання $є$ змішаною формою власності, бо учні навчаються у державній професійній школі, а проходять виробниче навчання на базі приватних навчальних підприємств.

Особливості середньої професійної освіти у Німеччині вбачаємо у тому, що професію можна отримати не в усіх типах закладів профресійної освіти, а лише у професійних, в професійно-технічних і школах середнього медичного персоналу, а також у коледжах [2, с. 45].

Технічні школи переважно, хоча і зараховують до закладів середньої професійної освіти, вирішують завдання підготовки до вступу у вищу профресійну школу, так як і професійні училища, переважно готують до вступу в технікуми.

Ще одна особливість середньої професійної освіти в Німеччині полягає в тому, що не зважаючи на те, що заклади середньої професійної освіти дають повну середню освіту, не всі випускники цього рівня навчання мають можливість вступу до вищих або професійних вищих шкіл, бо поняття "повна (неповна) середня освіта" у Німеччині не використовується, а є поняття різних рівнів зрілості: “вузівська зрілість” (після гімназії і дуального навчання дає можливість вступу у будь які вищі навчальні заклади); “професійно-вузівська зрілість” (після технічної школи дає можливість вступу тільки у професійні вищі школи); "технікумовська зрілість" (після професійного училища-вступ у технікуми), “середня зрілість” (після професійно-технічної школи не дає можливості вступу у вищі школи і технікуми). “Але жодна з гілок професійної освіти не $є$ тупіковою" [2, с. 46].

Спеціальні іспити дозволяють при переході з одного навчального закладу до іншого отримати більш високий рівень зрілості і таким чином здійснити можливість для продовження освіти і підвищення своєї кваліфікації (перекваліфрікації).

Створення в системі середньої професійної освіти оптимальних умов для продовження освіти, незвичайна комбінація типів, фрорм і термінів навчання, наявність “спеціальних іспитів", забезпечує привабливість для молоді Німеччини системи середньої професійної освіти. За різними джерелами через 
систему середньої професійної освіти Німеччини проходить від половини до 2/3 молоді віком від 16 до 19 років.

Дуальна система професійного навчання в Німеччині - ще одна 3 характерних особливостей німецької системи професійної освіти, що відрізняє її від системи освіти інших економічно розвинених країн.

Офріційне закріплення “дуальна система" отримала у 1964 році, хоча відлік розвитку дуального навчання в Німеччині датують серединою XIX століття.

Дуальна система - це поєднання навчання у професійній школі і безпосередньо на виробництві. Але акцент у дуальній освіті робиться на виробництво, тому дуальне навчання досить часто називають "виробничим навчанням".

Дуальна система навчання надає випускникам (при умові успішного складання іспитів не нижче певного рівня) можливості для підвищення кваліфікації, такі ж, наприклад, як і гімназія, на відміну від деяких інших типів закладів середньої професійної освіти.

Для того, щоб вступити у професійну школу в межах дуальної освіти, необхідно спочатку знайти місце учня на виробництві, пройти тести або іспити на підприємстві і тільки при позитивних результатах відбору, підприємство укладає угоду з учнем, у якій визначаються терміни навчання, права і обов'язки учня, тривалість робочого дня і відпустка, розмір винагороди і т.ін. I тільки тоді вирішується питання, у якій професійній школі буде навчатися претендент на місце для навчання в дуальній системі.

Іншою особливістю дуального навчання $€$ розподіл повноважень між підприємством і професійною школою щодо учня. Професійні школи і підприємства мають різний правовий статус, різних засновників, різні джерела фрінансування. Засновниками виробничого навчання зазвичай постають приватні підприємства, засновниками професійних шкіл - державні установи. Виробниче навчання регулюється федеральним законодавством, професійні школи підпорядковуються органам управління освітою федеральної землі. Фінансування виробничого навчання здійснює підприємство, професійної школи - федеральні землі, округи, спільноти.

Більш того, кожна професійна школа має свої особливості в організації і змісті процесу навчання, напрямах підготовки, розподілі навчального часу між професійною школою і підприємством.

Але співвідношення навчальних годин на виробниче навчання (на підприємстві) і навчання у профресійній школі приблизно однаково і зазвичай складає 70\% до 30\%. Таким чином на навчання на підприємстві відводиться 34 дні на тиждень, на навчання у професійній школі зазвичай -1 чи 2 дні на тиждень, іноді 1,5 дня (від 8 до 12 годин на тиждень), тоді підприємство може на другий день організувати заняття на виробництві.

До інших типів закладів середньої професійної освіти зараховують:

- профресійно-технічні школи (Berufsfachschulen) - 1-3-річні денні середні професійні навчальні заклади, що забезпечують підготовку за технічними, соціальними, торгівельними, гірничо-будівельними, сільськогосподарськими і 
іншими спеціальностями. Можливо продовження освіти в дуальній системі або після двохрічного навчання перехід в технічну школу;

- технічні школи (Fachoberschulen) - середні профресійні навчальні заклади після завершення яких випускник отримує посвідчення "профресійновузівської зрілості" і може продовжити навчання у профресійних вищих школах. Термін навчання - від 1 до 3-х років залежно від форми навчання;

- профресійні училища (Berufsaufbauschulen) - середні профресійні навчальні заклади для осіб, які переважно, вже мають спеціальність. Терміни навчання від 1 до 3 років залежно від фрорми навчання, можливість продовжити профресійне навчання в технікумі;

- технікуми (Fachschulen). На відміну від зазначених вище, технікуми -це середні професійні навчальні заклади 3-го щабля навчання для тих, хто вже має середню професійну освіту, профресію і бажає підвищити свою кваліфікацію (практично, це заклад підвищення кваліфікації). Форми навчання: денна (термін навчання від 6 місяців до $3-x$ років) і вечірня (від 6-до 8 семестрів).

Технікум дозволяє отримати поглиблену професійну освіту і кваліфікацію, наприклад, майстра, техніка, економіста, організатора виробництва і т. ін.

Технікуми i школи середнього медичного персоналу, зазвичай $€$ приватними закладами (за різними даними, від 30-40\% від загальної кількості закладів професійної освіти цього типу).

Згідно сьомої статті Конституції ФРН, фрінансування професійної освіти знаходиться під контролем держави, а законодавство і управління в системі освіти- переважно в компетенції земельних федеральних урядів. У законодавчих актах останніх визначаються цілі освіти і виховання, організація навчального процесу і т.ін. Саме вони приймають рішення про відкриття нових навчальних закладів і здійснюють нагляд за їх діяльністю.

Натомість сфрерою вищої і професійної освіти у ФРН займаються як Федеральне Міністерство освіти і наукових досліджень Німеччини, так і відповідні міністерства федеральних земель. Федеральне Міністерство освіти і наукових досліджень Німеччини вирішує стратегічні проблеми розвитку системи освіти, займається плануванням на рівні наступному середньому, розв'язує питання розвитку науково-дослідницької діяльності закладів вищої освіти. У деяких федеральних землях система освіти перебуває у веденні єдиного міністерства, у інших землях управління навчальними закладами здійснюють різні міністерства. У кожній федеральній землі нагляд і управління середньою освітою здійснюється на трьох рівнях: міському, окружному i земельному. Таким чином, така структура управління робить неоднорідною систему освіти різних земель.

Отримання професійної освіти оплачується батьками учнів в залежності від рівня їх доходів. Також $є$ можливість отримати стипендії для навчання у професійній школі.

Окрім цього, фрінансування підготовки може здійснюватися ще з двох джерел. По-перше, дуальна система забезпечується із федерального 
бюджету. По-друге, найбільш значний внесок роблять самі працедавці, які організовують і фрінансують виробниче навчання. Зазначимо, що у цьому випадку для підприємств знижується податок на ту суму, яку вони витратили на навчання, і ця міра $€$ одним 3 ефеективних способів стимулювати підприємства до відкриття власних освітніх майданчиків.

Реформи середньої профресійної освіти Німеччини у XXI столітті пов'язані 3 подальшим розвитком принципів і засад дуальної системи 3 метою усвідомлення того, в чому специфіка і чому вона тривалий час забезпечувала Німеччині найбільш низькі показники безробіття.

Перш за все, така організація професійної освіти ґрунтується на теорії безперервної освіти, прийнятті тотожності і успішності інтеграції у суспільство мігрантів і отримання ними робочих навичок, а також на розподілі відповідальності за профресійне навчання між державою і економічним сектором.

Тривалість навчання в системі дуальної освіти обіймає 2-3,5 роки залежно від обраної спеціальності. Підприємство укладає угоду на навчання 3 претендентом, але для організації процесу навчання, підприємство повинно мати дозвіл отриманий від Торгово-промислової або Ремесничої палати за умови виконання необхідних вимог.

“Підприємство може навчати тільки тим спеціальностям, які охоплюють профріль його діяльності, але повинно мати необхідне обладнання, необхідне забезпечення (навчальні програми, професійні журнали і літературу), достатню кількість професійних майстрів, навантаження яких дозволяє здійснювати кураторство учня. Ці майстри повинні бути сертифіковані Торговопромисловою або Ремесничою палатою" [6, с. 96].

Існує також система квотування на підприємствах: на трьох кваліфікованих спеціалістів один учень. Контроль за навчанням на виробництві здійснює Торгово-промислова або Ремеснича палати. Навчання у профресійних школах (освітніх центрах) контролює держава.

Федеральний уряд Німеччини відповідальний за розробку концепції підготовки за професіями в межах дуальної системи. Підготовка здійснюється виключно згідно норм, затверджених урядом. Функції держави - регулювання законодавчої бази і координація всіх учасників дуальної системи [7].

У різних джерелах, що обіймають опис системи дуальної освіти, висвітлено різні переваги цієї системи для учнів, підприємств, держави.

Так до переваг для учнів зараховують: навчання, що наближене до практики; виплату стипендії впродовж всього періоду навчання; вірогідність отримати роботу на тому підприємстві, де організовано навчання; значний попит випускників дуальної системи навчання на ринку праці; міжнародне визнання дипломів, можливість для побудови кар'єри.

Переваги дуального навчання для працедавця: забезпечення потреби підприємства у кваліфрікованих спеціалістах, зменшення плинності кадрів, відсутність фази адаптації молодих спеціалістів, омолодження середнього віку персоналу, підвищення іміджу виробництва і т.ін. 
Переваги дуальної системи навчання для держави: така освіта сама себе фінансує і забезпечує ринок праці конкурентоздатними робітниками.

У Німеччині у всіх фредеральних землях обов'язкове відвідування профресійної школи. За відвідування професійної школи відповідають самі учні, які досягли 18 років, і вчителі і батьки, поки учні не досягнули повноліття.

Профресійні школи в межах дуальної системи -партнери підприємств, що здійснюють спільне навчання в межах узгоджених навчальних планів і програм. Тривалість навчання в школах - до 12 годин на тиждень, викладачі професійних шкіл беруть участь у проведенні підсумкових іспитів, але оформлення результатів іспитів і видача дипломів не входить у коло повноважень профресійних шкіл.

Диференціація професійних шкіл, напрям яких визначається господарською структурою фредеральних земель або принципами пріоритетів профресій, орієнтованих на розвиток промисловості конкретних територій.

Доповнюють професійне навчання навчання на підприємствах, переважно малих і середніх.

Міжвиробничі навчальні центри, які учні відвідують декілька тижнів на рік виконують наступні функції:

- вирівнювання відмінностей у рівні профресійного навчання;

- ознайомлення з виробничими технологіями і забезпечення формування тих технічних навичок, які не можна або поки не можна опанувати на підприємствах;

- транссрерт інновацій на підприємствах [7, с. 98].

Навчанням невстигаючих, а також учнів з розумовими і фрізичними відхиленнями здійснюють реабілітаційні професійні училища. Вони фрінансуються приватними організаціями і фрондами і замінюють професійне навчання на виробництвах у тій частині, у якій міра фрізичної або розумової інвалідності підлітка не допускає профресійне навчання ні підприємстві [7, с. 100].

Німецькі дослідники М. Міллєр (M. Miller) [6], Р. Хенсен (R. Hensen) [7] вважають, заклади середньої професійної освіти Німеччини потребують змін:

- в школах необхідно посилити загальноосвітню підготовку;

- з метою профрілізації дуальної системи навчальний рік визначається спільно з підприємствами;

- для мігрантів і невстигаючих учнів необхідно створити дворічний курс (підготовчий рік і рік основного навчання);

- для унікальних професій з малою кількістю учнів необхідно створити "інтегровані спецкласи", при цьому важливо розвивати дидактично-методичні концепції "багатоперспективного розвитку компетенцій”, як потенційної інновації профресійної освіти;

- для самих учнів необхідно передбачити особливі, додаткові пропозиції в сфрерах економіки і іноземних мов, а також додаткові свідоцтва (дипломи) про профресійну додаткову кваліфрікацію (наприклад, асистен підприємствапомічник завідуючого відділом, майстер цеху, завідувач виробництвом).

Наразі створені нові Положення з 246 навчальних професій, що узгоджені 
з орієнтовними навчальними програмами для профілю. На підставі аналізу нових Положень для навчальних професій можна простежити наступні тенденції у процесі модернізації професійної освіти ФРН,

1.У наслідок широко профрільної профресійної підготовки, злиття (укрупнення) споріднених професій, а також посилення базового професійного навчання відбувається зменшення кількості навчальних профресій.

2. Разом із зменшенням кількості навчальних професій внаслідок соціального і економічного розвитку суспільства являються нові професії, такі як, наприклад, збирач побутових промислових відходів.

3 внесенням цих професій до каталогу навчальних професій ФРН було зроблено перший крок в напрямі розвитку сучасної професійної підготовки в сфрері захисту оточуючого середовища.

2. У нових Положеннях про організацію професійної підготовки висвітлено комплексні вимоги до професій нового типу. Учні повинні "мати здатність до самостійного планування, проведенню і контролю за своєю діяльністю".

Таким чином, поняття “профресійне навчання" розглядається з сучасних позицій за багатьма вимірами. 3 метою його повної характеристики доцільно назвати разом з цілеспрямованим мисленням, здатність до роботи у колективі, готовність до постійного підвищення кваліфікації для швидкого реагування на зміни профеесійних вимог.

Використання інформаційних технологій спричинило створення нових педагогічних і дидактичних концепцій у навчанні на виробництві і у професійній школі. У креслено-промисловій і комерційній сфрерах перед персоналом формулюються завдання-разом із спеціальною компетенцією розвинути також і здатності до самостійної роботи, до роботи у малих колективах, готовність до постійного підвищення кваліфікації, до природоохоронних економічно виважених дій.

Орієнтація німецьких підприємців на нові форми організації праці (гнучка поточна лінія, індивідуальна зборка, виконання багатьох видів робіт малими колективами і т.ін.) визначила якісно новий контекст розвитку профессійної освіти. Нові технології вимагають від учнів на підприємстві і в профресійній школі готовності до постійного підвищення кваліфікації.

Традиційний метод "трьох кроків" (демонстрація, відтворення, вправи) змінили сучасні методи: метод проектів, метод спрямовуючого тексту, метод діяльнісно-орієнтованого навчання, що ґрунтуються на концепції "саморегуляції учіння". Змінюється позиція персоналу в процесі професійного навчання: 3 трансляторів знань вони перетворюються на консультантів, радників.

Висновки і перспективи подальших досліджень. Схарактеризовані особливості фуунціонування професійної системи освіти ФРН кінця XX початку XXI століття дозволяють виокремити наступні основні напрями, які варто враховувати при модернізації професійної освіти в Україні:

- стратегічний підхід до питань професійної освіти;

- цілеспрямований розвиток мережі узгодженої системи підготовки 
кваліфрікованих кадрів спільно з промисловими колами і з ситемобю зайнятості; - врахування експертів, профресіоналів при фрормування політики і

прийнятті рішень;

- зростаюча координація і співпраця спеціалістів в сфері підготовки кваліфрікованих робітничих кадрів у європейському масштабі.

Подальшого дослідження потребують сучасні концепції підготовки кваліфікованих робітників з позицій дуальної форми професійної освіти.

\section{Використана література:}

1. Бойчевська І. Б. Роль системи дуальної освіти у професійній підготовці молоді у Німеччині. Порівняльно-педагогічні студії. Вип. 2. Умань : ПП Жовтий О.О., 2009. С. 68-74.

2. Джуринский А. Н. История педагогики и образования. Сравнительная педагогика [Текст] / Моск. пед. гос. ун-т. Москва : Прометей, 2009. 36 с.

3. Дуальна освіта в діалозі [Електронний ресурс] : звіт про виконання та результати проекту, а також рекомендації: реалізація проекту здійснена в рамках програми М-ва інозем. справ ФРН “Розбудова співпраці з громадянським суспільством в країнах східного партнерства та Росії, часові рамки виконання проекту: 01.06.2016 - 31.10.2017 / Партнери проекту: Представники громад. сусп-ва України і Німеччини ; координатори проекту: Іван Гаврилюк, Райнхард Дуддек // Федерація роботодавців України : [офіц. сайт]. Текст. дані. Київ, 2017. Режим доступу: http://fru.ua/images/Projektbericht_2017-08-14_ukr_V-1.pdf (дата звернення: 02.08.2018). - Назва 3 екрана.

4. Мирошниченко К., Савченко I. Упровадження елементів дуальної системи в професійній підготовці кваліфікованих робітників в Україні. Проф.-техн. освіта. 2017. № 2. С. 58-61.

5. Підготовка учнів ПТНЗ до планування й реалізації професійної кар'єри: теорія і практика : монографія / С. В. Алєксєєва, Д. О. Закатнов, В. Ф. Орлов [та ін.] ; за наук. ред. Д. О. Закатнова. Київ : ТОВ “НВП Поліграфсервіс", 2014. 196 с.

6. Miller M. D. Principles and a philosophy for vocational education. - Columbus, OH: The National Center for Research in Vocational Education, the Ohio State University, 1985. 250 p.

7. Hensen R. F., Hippach-Schneider U.VET in Europe - Country Report Germany.10 td ed. Bonn, Germany: BIBB, 2013.

\section{References:}

[1] Boichevska I. B. Rol systemy dualnoi osvity u profesiinii pidhotovtsi molodi u Nimechchyni. Porivnialno-pedahohichni studii. Vyp. 2. Uman : PP Zhovtyi O.O., 2009. S. 68-74.

[2] Dzhurinskij A. N. Istoriya pedagogiki i obrazovaniya. Sravnitelnaya pedagogika [Tekst] / Mosk. ped. gos. un-t. Moskva : Prometej, 2009. 36 s.

[3] Dualna osvita $\mathrm{v}$ dialozi [Elektronnyi resurs]: zvit pro vykonannia ta rezultaty proektu, a takozh rekomendatsii: realizatsiia proektu zdiisnena v ramkakh prohramy M-va inozem. sprav FRN "Rozbudova spivpratsi z hromadianskym suspilstvom v krainakh skhidnoho partnerstva ta Rosii", chasovi ramky vykonannia proektu: 01.06.2016 - 31.10.2017 / Partnery proektu: Predstavnyky hromad. susp-va Ukrainy i Nimechchyny; koordynatory proektu: Ivan Havryliuk, Rainkhard Duddek // Federatsiia robotodavtsiv Ukrainy: [ofits. sait]. Tekst. dani. Kyiv, 2017. Rezhym dostupu: http://fru.ua/images/ Projektbericht_2017-08-14_ukr_V-1.pdf (data zvernennia: 02.08.2018). - Nazva z ekrana.

[4] Myroshnychenko K., Savchenko I. Uprovadzhennia elementiv dualnoi systemy v profesiinii pidhotovtsi kvalifikovanykh robitnykiv v Ukraini. Prof.-tekhn. osvita. 2017. № 2. S. 58-61.

[5] Pidhotovka uchniv PTNZ do planuvannia y realizatsii profesiinoi kariery: teoriia i praktyka : monohrafiia / S. V. Alieksieieva, D. O. Zakatnov, V. F. Orlov [ta in.] ; za nauk. red. D. O. Zakatnova. Kyiv : TOV "NVP Polihrafservis", 2014. 196 s.

[6] Miller M. D. Principles and a philosophy for vocational education. - Columbus, OH: The National Center for Research in Vocational Education, the Ohio State University, 1985. 250 p.

[7] Hensen R. F., Hippach-Schneider U.VET in Europe - Country Report Germany.10 td ed. Bonn, Germany: BIBB, 2013. 
ДуБИНА Л. О. Особенности функционирования профессиональной системы образования Федеральной Республики Германии.

В статье подана характеристика особенностей функиионирования системы профессионального образования Федеральной Республики Германии (ФРГ). Дуальная система профессионального обучения в ФРГ - это одна из характерных особенностей немеикой системы профессионального образования, которое отличает её от системы образования других экономически развитых стран. В результате анализа литературы выявлен адаптаиионный потенциал системы профессионального образования ФРГ для украинской системы профессионального образования. Схарактеризовано тенденции развития и модернизачии немеикой системы профессионального обучения.

Ключевые слова: профессиональное образование, профессиональное обучение, производственное обучение, дуальная система, ученики.

DUBYNA LARYSA. Features of the functioning of the professional education system of the federal republic of germany.

The article describes the characteristics of the functioning of the vocational education system of the Federal Republic of Germany (Germany). The dual vocational training system in Germany is one of the characteristic features of the German vocational education system, which distinguishes it from the education system of other economically developed countries. As a result of the literature analysis, the adaptive potential of the VET system for the Ukrainian VET system has been identified. The tendencies of development and modernization of the German vocational training system are characterized.

Keywords: vocational education, vocational training, industrial training, dual system, students.

DOI: https://doi.org/10.31392/NZ-npu-144.2019.11

УДК 378.091:785

Економова О. С., Бутенко Т. М., Гаркуша Л. І.

\section{ФОРМУВАННЯ ІНСТРУМЕНТАЛЬНО-ВИКОНАВСЬКОЇ КОМПЕТЕНТНОСТІ МАЙБУТНЬОГО ВЧИТЕЛЯ МУЗИЧНОГО МИСТЕЦТВА У ФОРТЕПІАННОМУ КЛАСІ}

У статті досліджено науково-педагогічні основи формування інструментально-виконавської компетентності майбутнього вчителя музичного мистецтва в системі університетської освіти. Проаналізовано прачі вітчизняних і зарубіжних учених з проблем реалізащії компетентнісного підходу в освітньому прочесі мистецьких факультетів (інститутів). Узагальнено програмні вимоги з основного музичного інструменту для студентів музично-педагогічної спеціальності. Охарактеризовано основні види інструментальної діяльності вчителя музики та визначено роль фортепіано у його фаховій підготовиі. Окреслено найбільш складні аспекти інструментально-виконавської підготовки студентів у фортепіанному класі. Розкрито сутність і складові інструментально-виконавської компетентності майбутнього вчителя музичного мистецтвв.

Ключові слова: майбутній учитель музичного мистецтва; фахова підготовка; основний музичний інструмент; фортепіанний клас; компетентнісний підхід; інструментально-виконавська компетентність.

Розвиток вітчизняної системи вищої освіти на сучасному етапі передбачає впровадження у професійну підготовку майбутніх учителів компетентнісного підходу, що забезпечить формування у студентів комплексу 